\title{
The relevance and necessity of contextualising theological education and ministerial formation in South Africa
}

\begin{tabular}{|c|c|}
\hline \multicolumn{2}{|c|}{$\begin{array}{l}\text { Authors: } \\
\text { Jonathan M. Womack }{ }^{1} \text { (D) } \\
\text { Graham Duncan }{ }^{1} \text { (D) } \\
\text { Jerry Pillay }{ }^{1} \text { (D) }\end{array}$} \\
\hline \multicolumn{2}{|c|}{$\begin{array}{l}\text { Affiliations: } \\
{ }^{1} \text { Department of Church } \\
\text { History and Polity, Faculty } \\
\text { of Theology, University } \\
\text { of Pretoria, Pretoria, } \\
\text { South Africa }\end{array}$} \\
\hline \multicolumn{2}{|c|}{$\begin{array}{l}\text { Corresponding author: } \\
\text { Jonathan Womack, } \\
\text { jonnymwomack@gmail.com }\end{array}$} \\
\hline \multicolumn{2}{|c|}{$\begin{array}{l}\text { Dates: } \\
\text { Received: } 14 \text { Oct. } 2019 \\
\text { Accepted: } 07 \text { Feb. } 2020 \\
\text { Published: } 20 \text { Apr. } 2020\end{array}$} \\
\hline \multicolumn{2}{|c|}{$\begin{array}{l}\text { How to cite this article: } \\
\text { Womack, J.M., Duncan, G. \& } \\
\text { Pillay, J., 2020, 'The relevance } \\
\text { and necessity of } \\
\text { contextualising theological } \\
\text { education and ministerial } \\
\text { formation in South Africa', } \\
\text { Verbum et Ecclesia } 41(1) \text {, } \\
\text { a2059. https://doi.org/ } \\
\text { 10.4102/ve.v41i1.2059 }\end{array}$} \\
\hline \multicolumn{2}{|c|}{$\begin{array}{l}\text { Copyright: } \\
\text { (c) 2020. The Authors. } \\
\text { Licensee: AOSIS. This wo } \\
\text { is licensed under the } \\
\text { Creative Commons } \\
\text { Attribution License. }\end{array}$} \\
\hline \multicolumn{2}{|l|}{ Read online: } \\
\hline 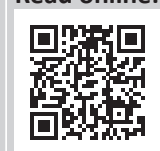 & $\begin{array}{l}\text { Scan this QR } \\
\text { code with your } \\
\text { smart phone or } \\
\text { mobile device } \\
\text { to read online. }\end{array}$ \\
\hline
\end{tabular}

Theology is never performed in a vacuum. One's context impacts on theology and life. Local peculiarities have a huge impact on the needs and expectations of individuals and society at large. Ignoring the local context can have a detrimental impact on the development of ministerial formation. Church history practised in the 21st century can no longer afford to be 'Eurocentric' and cut off from wider socio-economic development. This article analysed some of the key challenges ministerial formation in contemporary South Africa faces. Its primary focus is ministerial formation. Through this focus, the disciplines of history of Christianity, church polity, missiology and systematic theology are implicitly referred to. This article challenged the current discourse on ministerial formation to be aware of contextual dynamics and to avoid oversimplification of the matter. This task was achieved through a comparative methodology through a narrative analysis of aspects of society considered to relate directly to ministerial formation. These phenomena were grouped into those that are 'new' to democratic South Africa and those that have remained since the dawn of democracy. Although current discourses have tended to focus on aspects of change or continuation, this article concluded by highlighting how both change and continuation need to be taken into consideration. This research showed that South Africa presents a dynamic context in which ministerial formation is to take place. Only when the dynamic context of contemporary South Africa is truly taken into consideration can effective development to ministerial formation occur.

Intradisciplinary and/or interdisciplinary implications: This work, focussing on contemporary South Africa, identifies the necessity of including a contextual awareness in ministerial formation. It involves the disciplines of history of Christianity, church polity, missiology and systematic theology. It challenges the current discourse on its awareness of contextual dynamics and to avoid oversimplification of the matter.

Keywords: theology; contextual; Africanisation; contextualisation; ministerial formation; theological education; change and continuation.

\section{Introduction}

Traditional theology, which dominated the colonial period and immediately after independence, is not adequate to address the various social, religious, economic and political problems and challenges prevalent in the African continent. To address these problems and challenges, new theologies that are relevant to the African reality on the ground are being developed (Amanze 2009:120-121).

South Africa is a diverse and complex society. In this society, many new challenges are arising although more long-lasting challenges continue to impact contemporary society. Much research has been devoted to investigating these old challenges and the new struggles. Yet, research tends to focus on new issues of continuing struggles, often focussing on one specific issue within that field. As such, this article aims to draw awareness to the change in the South African society and its impact on theological education. In one sense, everything has changed in South Africa since the dawn of democracy. But in another very real sense, nothing has changed. This article will thus create an awareness of the dynamic and challenging context in which ministerial formation in South Africa is to take place. The challenges facing South Africa will thus be split into new and old, change and continuation. Challenges will be delimited to only include issues with a clearly identifiable link to ministerial formation. For example, changes in the political landscape are only investigated inasmuch as it affected the accreditation of theological courses. Any greater investigation would move away from the focus of this article and would be unnecessary. In fact, the areas deemed necessary for investigation are the use of technology, 
the impact of commodification, accreditation, ecumenism, gender, decolonisation, the religious state of society and the church university relationship.

\section{Everything changed}

The advent of democracy changed the South African society radically, 'suddenly becoming a modern - secular, plural, democratic, fragmented - society' (Smit 2003:308). This somewhat sudden switch to democracy also brought it into the post-modern world coupled with all its complexities. The world in which South Africans lived had changed, and it would never be the same again. So, 'If you have a new world, you need a new church. You have a new world' (McLaren 2000:11). Old forms of education and theological reflection were no longer relevant and needed to change. A few voices in a young democratic society recognised this. De Gruchy (1995:13) highlighted that although the churches' mission never changes, its context does, and as such the church has to adapt to this new context. One of the things that needed to be addressed was poverty, for, as he wrote, 'democracy cannot be sustained and flourish where there is large scale poverty' (De Gruchy 1995:22). Commenting on the South African Council of Churches (SACC), Raiser (1995:33) remarked how the council had done the right thing at the right time, but now the ground was changing and so the council also needed to change. Chipenda (1995:39) also highlighted that with the loss of the single evil of apartheid, multiple social evils would perpetuate in South African society, and the church should not lose these foci. What these three authors highlighted is that there is awareness that a new dawn has risen in South Africa and that the context is now very different than before.

One of the biggest impacts on South African society was the sudden onset of postmodernity. Being in a modernised, globalised world had a vast effect on the context in which ministerial formation and theological education were taking place. The effects of globalisation are vast, and it is sometimes difficult to distil what was a direct result of globalisation and what came about through other causes. For our purposes, the topics of technology, accreditation, commodification and ecumenism shall form focus areas. These four focus areas have had a huge impact on the nature of ministerial formation. The rise of technology has the potential to completely transform pedagogical approaches in ministerial formation. Accreditation provides a form of quality control but can also be hard for churches to acquire and as such adds a further dynamic to formation. The rise of commodification in education is also understood to be changing the nature of education and thus warrants investigation. Finally, ecumenism and ecumenical approaches have been heralded as the only viable solution. Yet, with the perceived decline in ecumenism in the 21st-century South Africa, is this really a viable solution? These four areas are by no means presented as an exhaustive list but are considered key focus areas owing to their pertinence and direct impact on ministerial formation. Another area with large-scale effects is that of poverty. However, as the effects of poverty are so far-reaching, its investigation has been delimited. The effects of poverty will thus be explored through and in relationship to each of the four key focus areas.

\section{Technology}

The rise of modern technology has drastically changed the world in which we live. The development of the Internet, computers, mobile phones and smart devices has completely changed our access to information, the way we conduct business and the way in which we interact with the world at large. One can now search for the football results, order a pizza, buy a new television and participate in an international conference call, all from the comfort of one's own home and in many cases all from one device. As Oliver (2014:2) explained, we are living at the beginning of the fourth social revolution. The first social revolution was the development of language. This allowed more advanced communication and the transference of knowledge. The second was the invention of writing skills. This allowed for easier transfer of knowledge and for it to outlive its writer. The third social revolution was that of the printing press. This rapidly increased the production of written materials making them affordable for the masses. The fourth revolution, also termed the fourth industrial revolution, is the invention of the Internet, allowing ideas to be spread as never before and putting the power of knowledge at the fingertips of the individual (see Oliver 2014:2-3). 'Information technology based on the World Wide Web (www) is restructuring the economy, capitalism and society' (Hendriks 2012:2). A revolution is stressful, as it involves entering the unknown, and it brings about a complete paradigm change (Oliver 2014:2-3). It does not mean that we need to do away with our old tools, but we do need to consider their function in this new paradigm. "The "technological bluff" that creates the impression that there is almost nothing that is not possible with technology' needs to be avoided (Cloete 2017:2). Yet, there are certain benefits of technology that should be taken into consideration. Again, what follows is not an exhaustive list but a few key suggestions.

Firstly, distance/online learning can take the classroom to the learner. This can provide huge benefits for learners who cannot afford, for whatever reason, to study outside of their home community. Distance education brings the material to them, often at a reduced cost. In terms of ministerial formation, Naidoo (2012) suggested that a few benefits may be attached to this approach. Secondly, distance education is more accessible and, as such, can train lay persons as well as those seeking ordained ministry (Naidoo 2012:2). In South Africa and Africa at large, where the growth of Christianity far outpaces the growth of Christian leadership, the ability to reach the masses through technology can have a positive impact. Another benefit is that learners remain in their local context and can immediately apply their theoretical knowledge to the lived situation (Naidoo 2012:7). As will be explored below, the lack of contextualisation of theological education is a key challenge facing the discipline. Thus, it is argued that distance education is more contextual and can aid in the contextualisation debate. Then, a further benefit 
raised by Cloete (2017:5) is that online education offers greater interaction within the class, as introverts feel more comfortable to partake in discussions. In theology, where formation, not simply knowledge acquisition, is the goal, increased discussion can be beneficial for personal development (see Cloete 2017:6).

Furthermore, benefits of technology can be found in its cost reduction and fluidity. Digital libraries and digital textbooks can reduce printing and distribution costs, helping to widen access to information. In relation to course design, not committing material to print allows for a fluidity to remain in the course. Not committing study guides or programmes to print allows the course to adapt to the needs and contexts as new challenges arise (cf. Naidoo 2012:4-5). The rise of technology has also brought with it an increased ability to network. One example is academi.edu, a platform specifically designed for students and lecturers to share and comment on their latest work and ideas (Academia.edu 2018). ${ }^{1}$ Furthermore, according to Oliver (2014), technology:

[...W]ill ensure a link between theology and other academic disciplines, as well as society in general. Technology and the mind-set of the network society can provide opportunities for interaction, broadening the audience for theology. (p. 4)

However, there are also dangers and challenges attached to technology. Although technology has the potential to increase access to learning, individuals still need access to appropriate devices and sufficient infrastructure for these devices to function effectively. Without a laptop and an Internet connection, the potential benefits are irrelevant (see Cloete 2017:4). In the 2013 household survey, it was estimated that only $10 \%$ of the population had access to the Internet at home, with the statistic rising to only $40 \%$ by the time access at a workplace, Internet cafés or other locations were included (Statistics SA 2014:52). With regard to household ownership of computers, this was estimated to be around $19.4 \%$ nationally. In areas classified as rural, household ownership of at least one computer was down to $6.6 \%$ (Statistics SA 2014:56). In effect, the number of South Africans who have access to technology and its potential benefits is very small. For the majority, these assets are simply not affordable or accessible. As a nation, South Africa is deeply gripped by a poverty crisis. This crisis deeply affects households' disposable income and access to technology. Statistically, it was estimated that in $2015,25.1 \%$ of the population was unemployed (The World Bank 2018:77). However, youth unemployment is higher. Between 2005 and 2015, 40\% of those aged between 20 and 29 years were unemployed (The World Bank 2018:78). In 2015, it was estimated that 55.5\% of the population was living in poverty (The World Bank 2018:7). ${ }^{2}$ As such, around half of those living in poverty are in employment, yet they do not earn enough to break the

1.Academia.edu (2018) described itself as a platform for academics to share research papers', with academics using the platform to 'share their research, monitor deep analytics around the impact of their research, and track the research of academics they follow'.

2.The estimated $55.5 \%$ is taken from the upper bound poverty line. In terms of food poverty, it was estimated around $25.2 \%$ of the population (see The World Bank poverty, it was estimated around $25.2 \%$ of the population (see The World Bank
$2018: 7-8$ ). On all counts, the percentage of those living in poverty in South Africa 2018:7-8). On all counts, the percentage of those livin
has decreased since 2005 but is still a high percentage. poverty cycle. In other words, only a minority has a disposable income to spend on technology and access its potential benefits.

The disembodiment of the learner also poses challenges. Although 'information could be stored via technology', it is argued that 'construction of knowledge and especially a lecture cannot be replicated online' (Cloete 2017:2-3). The lecture is a lived performance, which adapts to the mood and tone of the physically present class (Verene 2013:300). There is something in the physical presence that cannot be replicated in a digital presence. The loss of face-to-face learning also poses ethical challenges. It is much easier to fail a student when we do not know him or her or his or her personal situation (cf. Milgram 1974:32-36). ${ }^{3}$ 'Online education reduces students to clients and consumers of information' (Cloete 2017:3). This then leads to education simply being about knowledge acquisition and not personal, spiritual and emotional development, which is so vital to ministerial formation. This comes to the final problem, commodification. Technology, with the disembodiment of the individual and themass knowledgeproduction, is aiding the commodification of education. Commodification also presents a challenge in its own right and not just as a subset of technological advancements.

\section{Commodification}

With the rise of globalisation and changes in economic models, educational institutions went 'from being in the business of education into being in the education business' (Cloete 2017:5). Previously excluded from the global market, with the fall of apartheid and the lifting of international sanctions, South Africa soon found itself on a very different playing field.

Commodification refers to 'the action or process of treating something as a mere commodity' (Oxford English Dictionary 2018a). A commodity is a material or product that can be bought or sold; this traditionally referred to raw materials or primary agricultural products but now can be stretched to any product that meets a human need (cf. Oxford English Dictionary 2018b). As this article is focussing on the context of ministerial formation, it is the commodification of education that forms the specific interest. As a commodity needs to be sold globally, it is intentionally stripped of any contextuality to reach a mass market. In terms of education, commodification strips it of its essence and identity (Hadebe 2017:2). When we reflect on the task of ministerial formation, to prepare individuals for ministry in their local context, it is clear how the loss of context and subjectivity in education is detrimental to its very essence. 'Knowledge production is not an end in itself but must result in transformation of the society from which it arises from' (Hadebe 2017:7). Yet, when it becomes a commodity, knowledge production does become

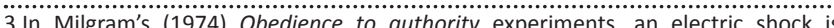
administer (1974) Obedience to authority administered to a learuer learner answers a question incorrectly. In two to four experiments, the distance between the learner and teacher is decreased with a recorded decrease in the mean maximum voltage administered. This experiment thus shows how personal contact makes it harder to administer damaging or painful consequences. 
an end. 'Universities are portrayed as businesses offering knowledge packaged and branded in the form of teaching programmes for sale to interested clients' (Naidoo 2017:2). Curriculum design thus comes to be tailored around the client with the greatest financial influence, rather than the needs of the local community. In a public lecture given by Mkhize (2018), the effects of this became clear. She highlighted how research projects are not chosen owing to their potential impact but on their ease and likelihood of publication. Their retail value, not their social value, is what mattered most to the university. Balia and Kim (2010:163) described how this has created a 'fast food' approach to education, which lacks any real depth or development.

As a result, education comes to be about knowledge production losing focus on personal formation. '[T] he value of education is measured in terms of what can be produced or consumed and becomes crassly utilitarian' (Naidoo 2017:2). Individuals are not treated as learners but as customers. In the case of Africa, Maluleke (2006:69) highlighted how this leads to black or African students being targeted as 'consumers of theological education rather than as interlocutors', where Africanisation becomes a 'cosmetic enterprise'. Real change is not sought; rather, that which will produce capital and does not upset the system becomes the focus. 'Commodification comes with the uncritical adoption of Western knowledge, which marginalises local customs and traditions' (Hadebe 2017:2). This then strongly relates to the conversation around contextualisation or Africanisation, which will be discussed later in this article.

With the focus on economic gain, competition not cooperation becomes the framing environment for education. Van Wyk (2017) illustrated this by comparing the current climate in theological education to that of the Hunger Games trilogy by Susan Collins. In the Hunger Games, competitors compete inside the ring (a panopticon environment) in a fight to the death until only one is left. This is likened to academia where we know the rules and engage in combat in the midst of our circle. In the academy, we fear for our job security and fiercely compete to keep publications and economic gain up. However, outside the ring there is a population trying to overcome an oppressive system. Much like South Africa, outside of the academy there is a population struggling to survive and make sense of the world. This is a population struggling to adapt to a new paradigm; a paradigm in which the 'West' is no longer the norm and Christianity is no longer the 'superior' religion, in which awareness of social inequality and ecological awareness are growing (Bosch 2016:192-193). Yet, it is also a context characterised by vast inequality (The World Bank 2018:43-44), where very few have access to higher education (Statistics SA 2014:17) ${ }^{4}$ and a means to change their reality. But the battle in the academic ring has become a distraction. Although focussed on competing, theological education has lost its relevance and it will only become

4.In 2013 , it was estimated that of individuals over the age of 5 years attending an educational institution, only $4.7 \%$ were attending a tertiary institution. In other
words, there is a large drop out between school and tertiary attendance (see Statistics SA 2014:18) relevant again if it deconstructs the arena it is trapped in (van Wyk 2017:260-261). Beyers (2016:7) highlighted how theology can either continue this status quo, entrenching itself further within its 'ivory tower' accessible only to those with financial means, or engage with society and work for social transformation. Yet, he highlighted how this is no longer a practical question but also an ethical one (Beyers 2016:7).

Finally, commodification greatly impacts access to education. 'As a developing nation with large poor communities, commodification denies many students access to higher education and opportunities to improve their lives, an issue of social injustice' (Hadebe 2017:2). With the rising cost of living and a focus on economic gain, education is becoming a luxury commodity only available to those who can afford it. Within a church environment, Du Preez, Hendriks and Carl (2014:2) highlighted how this is hindering church growth as only a few gifted potential leaders are receiving education. For those potential leaders who cannot afford the financial premiums, access is not granted.

\section{Accreditation}

With the fall of apartheid and the move from a Christian state to a secular state, theological institutions found that a new system of accreditation was imposed. This has led to national challenges for institutions to become accredited. Formed in 1965, the Joint Board for the Diploma in Theology was the official accrediting body for many ministerial formation programmes (see Duncan 2018:4). However, since 2005, the Joint Board has not been recognised by South African Qualification Authority (SAQA) or the Council on Higher Education (CHE). Starting in 1997, new legislation came into being. The National Qualification Framework afforded a level to each qualification assessed only by SAQA and CHE. In this new environment, many seminaries previously covered by the Joint Board had to apply for accreditation independently (see Richardson 2007:145). This was a costly process, which many institutions could not afford (cf. Church Unity Commission [CUC] 2018). ${ }^{5}$ Naidoo (2015:169) regarded this change in accreditation as the first domino in the eventual closure of many institutions. Yet, it is not only internally that accreditation has created challenges for ministerial formation, but on the other side of the equation and compounding the problem, international competition has also been introduced. Naidoo (2017:1) stated how South African students are often drawn more to international institutions, completing their degree via correspondence. Although Kalu (2006:236) claimed that, 'others simply buy certificates from fake operators or groups of Americans traveling through the developing world ordaining bishops and granting degrees as a way of building a worldwide network'. The loss of contextually rooted centres of learning coupled with the rise of international correspondence has led to a large amount of ministerial formation happening in a continually detached manner, or even not happening at all.

5.Richardson (2007:145) stated that a total of 19 seminaries had been accredited under the Joint Board and all needed to apply for accreditation. 


\section{Loss of ecumenism}

The ceasing of apartheid also saw the decline of ecumenism within South Africa. Although ecumenism did not disappear completely, commitment to it did subside. The simple example of the SACC serves to prove this point. A formidable organisation during the struggle, it is now a minor group that has lost its prophetic voice (see Göranzon 2011:473-493; cf. Pillay 2017). Reflecting on the situation, De Gruchy and De Gruchy (2005) commented:

The tragic irony of the church struggle against apartheid was that an ideology of apartness and exclusion provided the churches in South Africa with a sense of unity and cohesion. (p. 223)

After apartheid, unity and cohesion were replaced with a 'denominational myopia', with churches concerned more with their own needs than the needs at large. In contemporary society, it appears to be 'proximity to power, money, status, and the ruling parties', not working together to overcome social evils, which forms the main focus of churches (Makgoba 2015:502). Pillay (2017:3-4) has also highlighted how this proximity to power, the state, is detrimental to the ecumenical movement. As poverty is so extensive, partnership with the state to secure influence and wealth is often attractive. The SACC, when its financial status declined, adopted an approach of 'critical solidarity' with the state. However, it was more solidarity than critical, which resulted in compromises to the council's mandate (see Vellem 2013:180-182). It is no wonder that ecumenism in South Africa has been described as being in a 'state of crisis' (Maluleke 2005). Denominationalism is leading to private universities that focus on preserving their own church identity, which is degrading to the wider theological discussions (Amanze 2013:227-228). This is particularly evident in the number of Pentecostal colleges with strong ties and commitment to their mother institutions in the United States, which operate in South Africa. Although it is important for denominations to maintain their own identity, denominationalism goes beyond this, creating a negative environment for theological development and education (De Gruchy 1995:16-17). Ministerial formation is a multifaceted endeavour, and candidates can benefit greatly from learning in an ecumenical environment. Working in an ecumenical environment allows learners to be exposed to views other than their own. Furthermore, with the increased cost of learning, it is not viable for denominations to try and do it alone (CUC 2018).

No single African denominational church had the financial or human resources strong enough to build a confessionally exclusive 'centre of excellence' in theological education the only realistic way forward was through ecumenical co-operation (Saayman 2013:133).

Ecumenism can help spread the cost of education between various denominations. Ultimately, the loss of church unity is contrary to the gospel ${ }^{6}$ and as such needs to be overcome.

6.John 17:20-21.
Since the fall of apartheid, 'everything' has changed. Theological institutions are no longer operating in the same environment; some are no longer accredited. Furthermore, the immersion into post-modern society has radically changed the way theological education exists and is conducted. Technology has brought rapid changes to which educational institutions are still trying to adapt and embrace in the most beneficial manner. Then, education itself has become more and more a commodity, changing its very focus and essence. Some of the developments in the new South Africa have brought negative influences, yet others have been positive. Whether positive or negative, one thing is for sure, the context in which theological education is conducted has drastically changed since 1994.

\section{Nothing has changed}

In 2015 and 2016, South Africa witnessed the \#FeesMustFall and other student protest movements. ${ }^{7}$ The main catalyst for the protest movements was the proposed increase in tuition fees. Yet, although the catalyst, it cannot be attributed as the singular cause. Commenting at the time, Prof. Jane Duncan (in The Daily Vox 2017) believed that it was about:

$[D]$ emanding that education be delivered as a public good, or as a commons, and not as a commodity. In other words, the profit motive must be removed from education delivery. (n.p.)

Katlego Dismelo (Mail and Gaurdian 2015), then a PhD candidate at the University of the Witwatersrand, saw the protests to cover more than just one issue.

It is, firstly, about access to equal and quality education. It is about teasing out the ever so confusing intricacies of class relations in post-apartheid South Africa. It is about eradicating the painful exclusion and daily micro-aggressions that go hand-in-hand with institutional racism within these spaces. And, it is also about laying bare the failures of the heterosexual, patriarchal, neoliberal capitalist values that have become so characteristic of the country's universities.

The protest movements thus incorporated mass dissatisfaction with the current approach to education in South Africa, social unrest and discontent with life in post-apartheid South Africa, the perceived continuation of racial discrimination and colonialism. What the protest movements will be classed as is up for debate, ${ }^{8}$ yet what they do demonstrate is the lack of change in democratic South Africa. The \#FeesMustFall protest was the last straw with an educational system that refused to change and adapt to contemporary South Africa (cf. Amanze 2009:124; Le Grange 2016:10). What these protests serve to highlight is the lack of change within contemporary South African society. Although in one sense everything had changed, in another very real sense nothing had changed. Below issues pertinent to theological education, which have seemingly not changed since democracy, will be discussed.

7.\#ScienceMustFall and \#AfrikaansmustFall are two other key topics that received a lot of media attention at the time.

8.Le Grange (2016) described them as a class struggle and a rediscovery of identity. 


\section{Gender}

Gender and particularly discrimination against woman remain a pressing issue. Within South Africa, women are still more likely to live in poverty. In $2015,51.2 \%$ of femaleheaded households were in poverty (The World Bank 2018:13). Statistically, many young girls cannot attend school as they are expected to help at home (Statistics SA 2014:19). ${ }^{9}$ Then, within theological education, there still remains only a small, but growing, proportion of female candidates. Theological education in Southern Africa is shamefully behind in the empowerment of women and drafting their incorporation in the church and academics (Amanze 2013:232). 'Theological education is out of reach for the majority of African women' (Phiri 2009:11). Although institutions may accept the training of women, society still places expectations upon females that prevent them from studying. Furthermore, South African society for women is often a dangerous environment. The year 2018 saw protest movements against gender-based violence, although 2017 saw the hashtag \#MenAreTrash trending on twitter. For those who can study, they often end up receiving different qualifications to their male counterparts or different allocations in churches (Phiri 2009:111). Acceptance into a theological course does not mark the end of the segregation, although while studying or when seeking employment gender comes to play a decisive role. As such, the oppression of women still continues within theological education. Phiri (2009:112) claimed that 'there are more theological institutions in Africa that have no women on their staff than those that recruit women'. Of course there has been some change towards gender in South African society and ministerial formation, but the continuing narrative is one of discrimination and abuse. Commenting on her experience in the Uniting Reformed Church in Southern Africa, Mary Ann Platjies van-huffle (Huffel 2019) concluded that:

On the one hand women have been accepted in leadership roles within URCSA, but on the other hand the role of women has been limited in practice ... covert forms of patriarchy, notwithstanding all our policies and decisions on gender equality and gender equity, are still apparent in URCSA. The surface structures have been shifted at the General Synods but the dominant discourses that imprison women have remained the same. (p. 19)

Ministerial formation is in theory open to the training and inclusion of women, yet in practice still remains strongly patriarchal. All too often ministerial formation practices are influenced by the dominant narrative in South African society, but have often failed to influence that narrative.

\section{Decolonisation}

The decolonisation or contextualisation or Africanisation discussion has a vast array of literature written on it (see Amanze 2009; Hadebe 2017; Hendriks 2012; Le Grange 2016; Maluleke 2006; Naidoo 2010). As the purpose of this article was to highlight challenges within the South African context, an in-depth exploration of the topic will not be conducted. Rather, the point here is to flush out the key areas of debate. Decolonisation or contextualisation or Africanisation all represent different perspectives. They have been grouped together here, as their focus is on the lack of change within educational models since 1994 and the need to develop an educational system relevant to the needs of the local context. The plea for theological education to equip in the local context is a long-standing one. In Theological impotence and the universality of the church, Mbiti (1976) provided a poignant anecdote, which depicted the irrelevance of models of theological education in Africa and pleaded for this to change. In 2006, Maluleke (see 2006:61-62) again popularised this anecdote and pleaded for relevant theological education within South Africa. The main criticism has been that theological education is not changing. In spite of a global shift in Christianity, from the Northern to the Southern Hemisphere, educational forms and thought processes have not matched this shift (Wahl 2013:267). The effects of this have been vast and several key issues are listed below.

Firstly, theological education is in a fragile state. This is a global issue but is especially important in Africa. According to Houston (2013):

Most theological colleges in Africa are faithfully teaching the knowledge that was generated in the West because we are dependent on Western textbooks for so many of the courses we teach. (p. 109)

This dependence on the 'West' and inability to break its hold are leading to the perpetuation of an education that has no relevance in the immediate context. Maluleke (2006):

The African graduate has learnt well to ignore the questions that are being asked 'on the ground', to explain them away and to occupy himself with his own fabricated ones. (p. 67)

In line with not equipping, it is also seen that current forms are not relevant. Ministerial candidates do not learn to work in the local context, nor do they even study it. The 'colonial' model of education is entrenched in the secular, 'enlightened' world view, which promotes the importance of rationality at the expense of spirituality (Balcomb 2012:8-9). Yet, this is not the reality of the African world view. Further issues of relevance are found with the curriculum design. 'The dominant curriculum continues to be a source of alienation' (Naidoo 2016:2). Maluleke (2006):

It is still possible to attain a diploma or a basic degree in theology within (South) Africa and to do so without ever having read any work by an African. (p. 66)

Because of this lack of relevance, much of the education is done in the abstract, the consequence of which is students lack practical experience (Amanze 2013:229). In short, theological education is critiqued for not meeting the contextual reality of those studying. Institutions have started to address this situation and the situation is changing, although some feel that these changes have not gone far enough (Duncan 2016:7). 


\section{A religious society}

A final aspect of South African society, which has not changed since apartheid, is its strong spiritual and Christian presence. It is estimated that $85 \%$ of the population is Christian (Statistics SA 2014:32). In a recent study on the spiritual lives of students, Nell (2016:6) found that $98.9 \%$ of the sample were religious to some degree.

As Western Christianity struggled to survive secularisation from damaging ideologies of different revolutions, the churches in the Global South have demonstrated extraordinary vitality demographically and spiritually, with people of all ages and classes attending church activities and Sunday services (Gatwa 2010:321).

This is important for two main reasons. Firstly, it demonstrates the need for theological education. With such a high adherence to Christianity, there is a need to continually train or form ministers. Secondly, the approach of training needs to take account of the spiritual reality.

Theology in Africa - whether in or out of the academy - is accomplished by assuming not the absence but the presence of God; there is no interest in the social sciences, either as a means of explanation of religious phenomena (as these are essentially religious in nature, that is, they have transcendent causality) or as a means of measuring relevance, and there is no tradition of secular humanism when it comes to the notion of human rights and flourishing. This has profound implications for the way theology is being carried out in most parts of Africa (Balcomb 2012:10).

This vibrancy of faith should form a strong reason for academic theology to sit up and pay attention to the local context if it wants to assure its long-term success.

From this section, it has been seen that, in some regards, very little has changed in South Africa since 1994. South African society is still gripped by inequality and plagued with poverty. The forms of education being taught still perpetuate the old colonial system and lack a relevance to the local congregation. Yet, faith and spirituality have remained a strong part of South African society and provide a hope for the future of theological education within South Africa. With this continual presence, there is support for continual formation studies, although the unchanged challenges present an agenda for formation studies.

\section{Conclusion}

This article has established that South African society is a complex blend of change and continuity. With the fall of apartheid and the rise of the fourth industrial revolution, dramatic changes have taken place in the daily reality of every South African. Yet, at the same time, challenges of poverty, inequality and Africanisation or decolonisation still characterise South African society. This creates a challenging context within which ministerial formation takes place. The need to prioritise and promote the African context should feature strongly in ministerial formation. So, too, should an awareness of unequal access to education and measures put in place to make sure all able candidates, not only the financially able, can have access to ministerial formation. Ministerial formation in the South African context requires a serious review to enhance contextual and relevant ministry in the African context at large.

\section{Acknowledgements Competing interests}

The authors have declared that no competing interest exists.

\section{Authors' contributions}

All authors contributed equally to this work.

\section{Ethical considerations}

This article followed all ethical standards for research without direct contact with human or animal subjects.

\section{Funding information}

This research received no specific grant from any funding agency in the public, commercial or not-for-profit sectors.

\section{Data availability statement}

Data sharing is not applicable to this article as no new data were created or analysed in this study.

\section{Disclaimer}

The views and opinions expressed in this article are those of the authors and do not necessarily reflect the official policy or position of any affiliated agency of the authors.

\section{References}

Academia.edu., 2018, About Academia.edu, viewed 09 October 2018, from https:// www.academia.edu/about.

Amanze, J., 2013, 'Theological education in Southern Africa', in I. Apawo Phiri \& D. Werner (eds.), Handbook of theological education in Africa, pp. 223-233, Regnum Books, Oxford.

Amanze, J.N., 2009, 'Paradigm shift in theological education in Southern and Central Africa and its relevance to ministerial formation', International Review of Mission 98(1), 120-131. https://doi.org/10.1111/j.1758-6631.2009.00010.x

Balcomb, A.O., 2012, 'What theology ? Whose development ?: Interrogating theology and development in the secular academy', Journal of Theology for Southern Africa 142(4), 6-21.

Balia, D.M. \& Kim, K., 2010, Witnessing to Christ today, Regnum Books, Oxford.

Beyers, J., 2016, 'Theology and higher education: The place of a faculty of theology at a South African university', HTS Teologiese Studies/Theological Studies 72(4), 1-11. https://doi.org/10.4102/hts.v72i4.3450

Bosch, D., 2016, 'Paradigm changes in missiology', in D. Bosch (ed.), Transforming mission. Paradigm shirts in theology of mission. Twentieth anniversary edition, pp. 185-194, 5th edn., Orbis Books, Maryknoll, NY.

Chipenda, J., 1995, 'The church in Africa today', in B. Pityana \& C. Villa-Vicencio (eds.), Being the church in South Africa, pp. 38-42, South African Council of Churches, Johannesburg

Cloete, A.L., 2017, 'Technology and education: Challenges and opportunities', HTS Teologiese Studies/Theological Studies 73(4), 1-7. https://doi.org/10.4102/hts. v73i4.4589

Church Unity Commission (CUC), 2018, 'Conversation on theological education', in Church Unity Commission 50th celebration, Recording in possession of the author, Hillcrest, Pretoria, September 2018.

De Gruchy, J., 1995, 'Becoming the ecumenical church', in B. Pityana \& C. Villa-Vicencio (eds.), Being the church in South Africa, pp. 12-26, South African Council of Churches, Johannesburg. 
De Gruchy, J. \& De Gruchy, S., 2005, The church struggle in South Africa, 25th Anniv edn., Fortress Press, Minneapolis, MN.

Dismelo, K., 2015, 'Student protests are about much more than just \#FeesMustFall', Mail and Gaurdian, 29 October, viewed 01 September 2019, from https://mg. co.za/article/2015-10-29-student-protests-are-about-much-more-than-justfoesmustfall.

Duncan, G., 2018, 'The benefits and dangers for churches and ministry institutions to work in a regulated environment, with reference to professionalising religious practice via South African Qualifications Authority and the National Qualification Framework Act', HTS Teologiese Studies/Theological Studies 74(4), 1-13. https://
doi.org/10.4102/hts.v74i4.4802

Duncan, G.A., 2016, 'Gateway to the future... oopmaak van die hekke... transformation in the Faculty of Theology, University of Pretoria', HTS Teologiese Studies/ Theological Studies 72(4), 1-12. https://doi.org/10.4102/hts.v72i4.3424

Du Preez, K.P., Hendriks, H.J. \& Carl, A.E., 2014, 'Missional theological curricula and institutions', Verbum et Ecclesia 35(1), 1-8. https://doi.org/10.4102/ve. v35i1.1326

Gatwa, T., 2010, 'The cross-cultural mission. An agenda for theological education in Africa', Missionalia 38(2), 321-342.

Göranzon, A., 2011, The prophetic voice of the SACC after 1990: Searching for a renewed Kairos, Swedish Institute of Mission Research, Uppsala, viewed 01 September 2019, from https://urn.kb.se/resolve?urn=urn:nbn:se:uu:diva-151766.

Hadebe, N., 2017, 'Commodification, decolonisation and theological education in Africa: Renewed challenges for African theologians', HTS Teologiese Studies/ Theological Studies 73(3), 1-10.

Hendriks, H.J., 2012, 'Contextualising theological education in Africa by doing theology in a missional hermeneutic', Koers-Bulletin for Christian Scholarship 77(2), 1-8. https://doi.org/10.4102/koers.v77i2.56

Houston, B., 2013, 'The future is not what is used to be: Changes and choices facing theological education in Africa', in I. Apawo Phiti \& D. Werner (eds.), Handbook of theological education in Africa, pp. 108-106, Regnum Books, Oxford.

Huffel, M.P., 2019, 'A history of gender insensitivity in URCSA', Studia Historiae Ecclesiasticae 45(3), 1-22. https://doi.org/10.25159/2412-4265/6250

Kalu, O., 2006, 'Multicultural theological education in a non-western context: Africa, 1975-2000', in D. Esterline \& O. Kalu (eds.), Shaping beloved community: Multicultural theological education, pp. 225-242, Westminster John Knox Press, Louisville, KY.

Le Grange, L., 2016, 'Decolonising the university curriculum', South African Journal of Higher Education 30(2), 1-12. https://doi.org/10.20853/30-2-709

Makgoba, T., 2015, 'Ecclesiology and ethics: A critical self-reflection', The Ecumenical Review 67(4), 498-504. https://doi.org/10.1111/erev.12191

Maluleke, T.S., 2005, 'Reconciliation in South Africa: Ten years later', Journal of Theology for Southern Africa 123(November), 105-120.

Maluleke, T.S., 2006, 'The Africanization of theological education: Does theological education equip you to help your sister?', in E.P. Antonio (ed.), Inculturation and the postcolonial discourse in African theology, Peter Lang, New York.

Mbiti, J., 1976, 'Theological impotence and the universality of the church', in G. Anderson (ed.), Mission trends no. 3: Third world theologies, pp. 6-18, Eerdmans, Grand Rapids, MI.

McLaren, B., 2000, The church on the other side; doing ministry in the postmodern matrix, Zondervan, Grand Rapids, MI.

Milgram, S., 1974, Obedience to authority: An experimental view, Tavistock, London. https://doi.org/10.1037/h0038158

Mkhize, N.N., 2018, 'The appropriation and commodification of decolonisation in SA universities post-fallism', in Curriculum transformation matters: The decolonia turn, University of Pretoria, Pretoria.
Naidoo, M., 2010, 'Ministerial training: The need for pedagogies of formation and of contextualisation in theological education', Missionalia 38(3), 347-368.

Naidoo, M., 2012, 'Ministerial formation of theological students through distance education: Ministerial formational focus', HTS Teologiese Studies/Theological Studies 68(2), 1-9. https://doi.org/10.4102/hts.v68i2.1225

Naidoo, M., 2015, 'Ministerial formation and practical theology in South Africa', International Journal of Practical Theology 19(1), 164-188. https://doi. org/10.1515/ijpt-2015-0004

Naidoo, M., 2016, 'Overcoming alienation in Africanising theological education', HTS Teologiese Studies/Theological Studies 72(1), 1-8. https://doi.org/10.4102/hts. v72i1.3062

Naidoo, M., 2017, 'The globalising effect of commercialisation and commodification in African theological education', HTS Teologiese Studies/Theological Studies 73(3), 1-8. https://doi.org/10.4102/hts.v73i3.4577

Nell, W., 2016, 'The religious lives of students at a South African university', HTS Teologiese Studies/Theological Studies 72(1), 1-11. https://doi.org/10.4102/hts. v72i1.3177

Oliver, E., 2014, 'Theological education with the help of technology', HTS Teologiese Studies/Theological Studies 70(1), 1-8. https://doi.org/10.4102/hts.v70i1.2643

Oxford English Dictionary, 2018a, Commodification, viewed 09 October 2018, from https://en.oxforddictionaries.com/definition/commodification.

Oxford English Dictionary, 2018b, Commodity, viewed 09 October 2018, from https:// en.oxforddictionaries.com/definition/commodity.

Phiri, I.A., 2009, 'Major challenges for African women theologians in theological education (1989-2008)', International Review of Mission 98(1), 105-119. https:// doi.org/10.1111/j.1758-6631.2009.00009.x

Raiser, K., 1995, 'The church in global context', in B. Pityana \& C. Villa-Vicencio (eds.), Being the church in South Africa, pp. 27-37, SACC, Johannesburg.

Richardson, N., 2007, 'Ministerial training and theological education in the Methodist Church of Southern Africa: The road ahead', Missionalia 35(2), 131-152.

Saayman, W., 2013, 'Mission as theological education: Is Christian mission history coming full', Missionalia 41(2), 133-145. https://doi.org/10.7832/41-2-10

Smit, D.J., 2003, 'Unity in church and society? Theological reflections on an ongoing challenge in South Africa', Scriptura 83, 305-314. https://doi.org/10.7833/83-0-887

Statistics SA, 2014, General household survey 2013, Pretoria, viewed 01 September 2019, from https://www.statssa.gov.za/publications/P0318/P03182013.pdf.

The Daily Vox, 2017, We asked academics to weigh in on the \#FeesMustFall debate, viewed 01 September 2019, from https://www.thedailyvox.co.za/ asked-academics-weigh-feesmustfall-debate/.

The World Bank, 2018, 'Overcoming poverty and inequality in South Africa. An assessment of drivers, contraints and opportunities', in W. Hurlbut (ed.), International Bank for Reconstruction and Development, pp. 1-120, Washington, DC, viewed 14 March 2020, from https:// www.statssa.gov.za/wp-content/themes/umkhanyakude/ documents/South_Africa_Poverty_and_Inequality_Assessment_Report_2018.pdf.

Van Wyk, T., 2017, 'Let us play: (Un)shackling liaisons, (un)masking games and (un) hindered dialogue in the arena where theology takes place', in D.J. Human (ed.), Ecodomy: Life in It's fullness, Verbum et Ecclessia, 38(Suppl 1), pp. 246-280.

Vellem, V.S., 2013, 'Ecumenicity and a black theology of liberation', in E. Conradie \& R. Koegelenberg (eds.), South African perspectives on notions and forms of ecumenicity, pp. 173-183, Sun Press, Stellenbosch.

Verene, D.P., 2013, 'Does online education rest on a mistake?', Academic Questions 26(3), 296-307. https://doi.org/10.1007/s12129-013-9367-2

Wahl, W., 2013, 'Towards relevant theological education in Africa: Comparing the international discourse with contextual challenges', Acta Theologica 33(1) 266-293. https://doi.org/10.4314/actat.v33i1.14 